研究発表論文

\title{
思い出に残る自然風景に関する研究
}

\section{Characteristics and Structure of Memory of Landscape Past}

古谷勝則 ${ }^{*}$

\section{Katsunori FURUYA}

\author{
摘要 : 人が風景を体験し、強い感動を受けるような思い出に残る自然風景を調査した。一般社会人に \\ アンケートを送付して183名から回答を得た。体験年秢，視点場と視対象．体験した状況を整理・分 \\ 析し，以下の成果が得られた。1）視点場は，山頂や海岸，草原だけでなく，道路や展望台，橋も重 \\ 要である。2）視対象の構造は, 対象物の空間分布を視知覚で認識しているのに加え, 時間や季節の \\ 变化要因が自然風景に彩りを加えている。3）季節は夏と秋が多く，体験時間は午前中に $72 \%$ が体験 \\ している。空は晴れていて，陽射しが強く，明るい場合に，感動することが多い。一方，朝や夕方の \\ 風景も感動することが多い。温度や風の影響は少ない。
}

1.はじめに

自然と人間の共生した，潤いのある環境を創造保全していくた めには，規範となる風景を知る必要がある。従来から研究されて きた視覚認知できる風景の形や色彩の見え方の問題を検討するだ けでは，風景の共通性を体系化することはできない。本研究では， 人間が風景を体験し強い印象を受けるような「思い出に残る風景」 を研究することにより, 自然風景の視点場と視対象の整理から, 景観保全のための基礎資料を提供することを意図する。

景観研究では，研究用に用意された写真などを分析対象にして， 枠取られた静止景観の一部を分析する傾向があり，物理的対象物 の特徵や評価を検討することが多い1)。本来, 風景は目でとらえ る対象と心で意識された刘象が一体のものであるが，目でとらえ る研究に片寄る傾向がある。そこで，本研究では，思い出に残る 自然風景を調べることにより，心で意識された自然風景を明らか にすることを目的とした。研究の方法は，まず(1)人間の成長の過 程で自然風景が何才ごろ認識されるかを明らかにした後に，(2)初 めて思い出に残った自然風景の視点場と視対象を整理した。次に, (3)人生の中で最も感動した自然風景の視点場と視対象，体験した 状況を整理した。

風景の思い出に関する既往研究については，「体験された風景 の構造を対象と人間との関係で比較した煀ら の研究，青年の 「原風景」の特性之構造を風景のタイプで類型化した茂原ら ${ }^{37} の$ 研究，「好ましい景観」の類型化により共通性の体系化を行った 平尾ら "9研究，「原風景」の概念を「原環境」に拡張して住環 境の理想像の類型化を行った周ら ${ }^{57}$ の研究，東京農業大学 ${ }^{6)}$ の研 究室に在籍, 在職した 49 名の原風景をまとめて出版された「原 風景の研究」などがある。本研究はこれら前例を参考にしながら， 写真の趣味を持つ一般市民の自然風景の思い出を調査し，感動し た自然風景の視点場と視対象を分析するものであり，本研究の独 自性もここにあると考える。

\section{2. 調查方法と回答者の属性}

自然風景を主な対象とした写真コンクールに，国立公園協会が 主催している「国立公䞢国定公園写真コンクール」がある。この コンクールに応募する人々は，自然風景に対する造詣と経験が深 いと考え，写真コンクールに応募された方々を対象に，アンケー

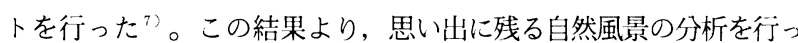

た。

調査は「自然風景の思いでに関する調査」と題して，郵送によ るアンケートを実施した。調査の概要と調査項目を戈一 1 に示し た。アンケートを1997年 4 月に送付し，183名の方々から回答 を得, 回收率は $49.1 \%$ であった。調査対象者は地域別に見ても 日本全国に広く分布している。アンケートは研究目的に添った内 容の設問に対し，風景のイメージ絵上説明文を記述させる方法を とった。ただし，記述にあたっては，完全な自由記述にするので はなく，風景を記述する文章を用意し，その文章に単語を記述し てもらう形式とした。例えば，初めて思い出に残った風景の設閭 では,「（）から（）を見ている風景」という文を 与え，この文の括弧を埋めてもらう方法をとった。この設問形式 を使う之，調罡目的に添った視点場之視対象を適切に把握し，調 查対象者自身の言葉を使って答えてもらえる利点がある。反面, 数值デー夕でないので処理が難しい。

回答者の属性を表一 2 に示した。回答者の平均年龄は, 54.3

\section{表 -1 調查の概要}

\begin{tabular}{|c|c|}
\hline 調查 時 $^{2}$ & 1997年 4 月 \\
\hline & （財）国立公尌協会が主催する \\
\hline 調直对嫁 & 定公園の写真コンクール!（1997年2月楴切）応募者 \\
\hline 調查方法 & 郵送法 \\
\hline 回答㤟数 & 183名（回収率49.1\%、配布数373名） \\
\hline $\begin{array}{l}\text { 地 理 的 } \\
\text { 分 布 }\end{array}$ & $\begin{array}{l}\text { 北海道 31名、東北 49名、関東 } 83 \text { 名、中部 65名、近 } \\
\text { 畿 } 68 \text { 名、中国 } 23 \text { 名、四国 } 16 \text { 名、九州 } 37 \text { 名、沖縄 } 1 \\
\text { 名 }\end{array}$ \\
\hline 調查項目 & 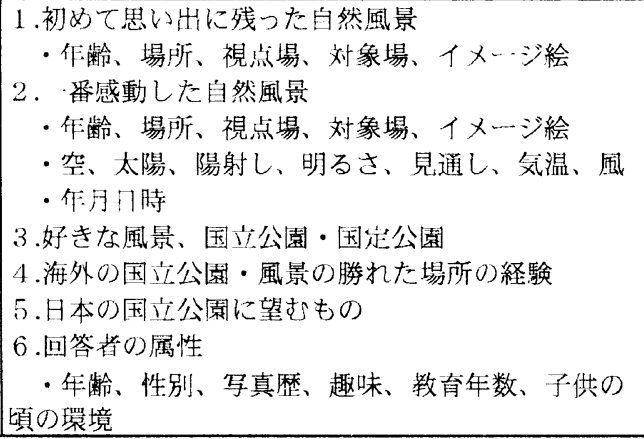 \\
\hline
\end{tabular}

•千葉大学園芸学部緑地・環境学科 
表 -2 回答者の属性

\begin{tabular}{|c|c|}
\hline 齢 & $\begin{array}{l}30 \text { 才未満 } 5 \text { 名、30才以上 } 45 \text { 才未満 } 34 \text { 名、45才以上 } \\
60 \text { 才未満 } 67 \text { 名、60才以上 } 74 \text { 名、未記入 } 3 \text { 名 } \\
\end{array}$ \\
\hline 性 & 男 170 名、女 12 名、未記入 1 名 \\
\hline 写真 歴 & $\begin{array}{l}\text { 3年末満 } 10 \text { 名、3年以上 } 10 \text { 年末満 } 30 \text { 名、10年以上 } \\
140 \text { 名、未記入 } 3 \text { 名 }\end{array}$ \\
\hline 教育年数 & $\begin{array}{l}\text { 10年 } 31 \text { 名、11 15年 } 88 \text { 名、16年以上 } 50 \text { 名、未 } \\
\text { 記入 14名 }\end{array}$ \\
\hline $\begin{array}{l}\text { 子供の頃 } \\
\text { 環 境 }\end{array}$ & $\begin{array}{l}\text { 自然に囲まれて育った } 148 \text { 名、自然の少ない所に育 } \\
\text { つた } 30 \text { 名、未記人 } 5 \text { 名 }\end{array}$ \\
\hline
\end{tabular}

歳であり, 回答者に, 中高年が多いと言える。また，性別では男 が 170 名, 女が 12 名でかなりの偏りが見られる。写真歴は, 10 年以上が 140 名であり, 多くの人が写真撮影を長くやっている愛 好家である。学歴では高等教育を受けた人の割合が高い。このこ とは平均年齢が高いことを考え合わせると，かなりの高学歴集団 だったといえる。写真以外の趣味では登山や旅行, 音楽, 美術な ぞが多く見られる。回答者の子供の頃の生活環境では, 全体の 80\%が子供の頃に自然に囲まれて育っている。これらアンケート 回答者の特性を見ると, 自然風景の一般論を導き出すには, 回答 者の属性が片寄っていると思われる。しかし，「国立公園国定公 園の写真コンクール」に応募する方々は, 自然風景の経験が豊富
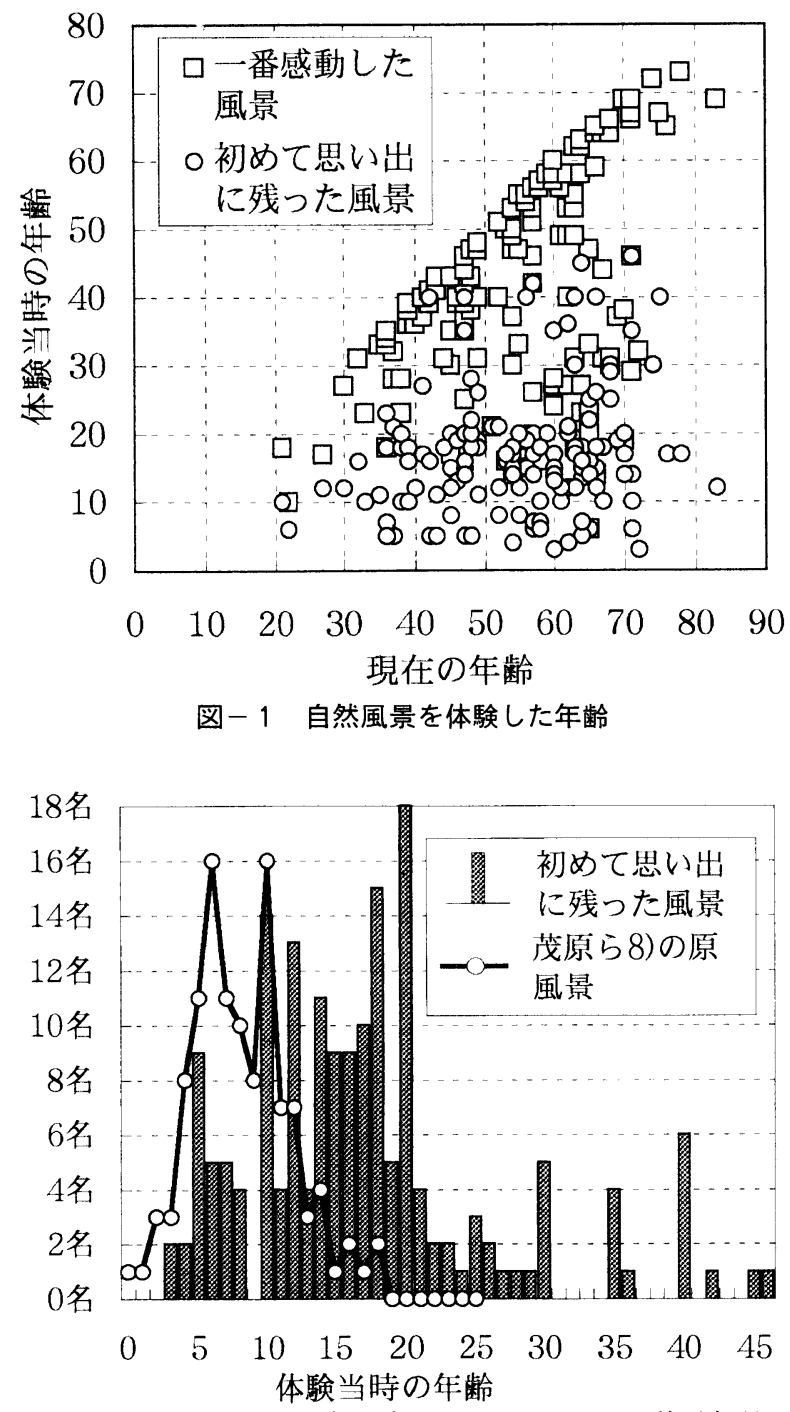

図ー2 初めての思い出に残った風景と原風景の体験年齢
であり，それら経験の中でも特に印象に残っている風景を回答す ることになるので, 特徵的な自然風景を調查するのに有効と考え た。

\section{3，自然風景を体験した年齢}

\section{（1）初めて思い出に残った自然風景}

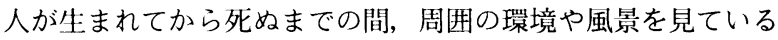
はずであるが，意識の上で周囲の自然環境を認識するようになる のは何才くらいであるのか。人はそれぞれに，意識の上で初めて 自然風景を体験し，思い出に残った年儈があるはずである。この 初めて思い出に残った歳の設問に対し，175名が回答してくれた。 回答者の現在の年齢と体験した年齢を図ー 1 に○印で示した。 初めての思い出は 3 才から 46 才まで, 幅広い年令に見られたが, 平均は 16.4 才である。回答者の年路に関係なく 20 歳以下で思い 出に残ると回答した人が多く，有効回答者の $80 \%$ を占めている。 次に, 青年の原風景を体験した年齢と比較するために, 茂原ら ${ }^{31}$ の研究の結果と比較したグラフを図ー 2 に示した ${ }^{8)}$ 。この図によ ると，茂原らの原風景を体験する年齢が 4 才から 12 才までの間 に多く分布しているのに対し, 思い出に残った自然風景では $5 才$ から 20 才までの幅広い年齢に分布している。この差は，茂原の 研究が原風景を対象に青年に質問しているの対し, 今回の調查が, 自然風景に限定して幅広い人に調查しているためと考えられる。 また，幼い頃の風景の記憶はディテールが喪失し断片的であり，

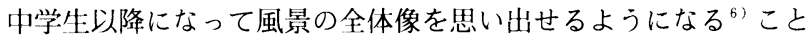
が多いので, 今回の調査対象のように自然風景に限定した場合, 体験の平均年齢が高くなることも考えられる。今回の調査では 3 才から 8 才までの体験が全体の $15.4 \%$ であり，10才から 20 才ま での体験が $64.0 \% ， 21$ 才以上の体験が $20.6 \%$ である。このこと から, 10 才以降 20 才前後までの思春期に思い出に残る自然風景 を体験している場合が多数有ることがわかった。進士は原風景を， 「幼少期ならびに思春期（20 歳前後）の生活環境の風景や体験の 全体像，風景のみならず風土・気候・人間・歴史などが醇し出す 原イメージや方言・習慣・体験などを含んだ原体験に，自分自身 の内面，すなわち内なる風景が一体になった個人の所産である」 ${ }^{97}$ と定義している。本研究で明らかにした幼少期ならびに思春期に 思い出に残った自然風景体験が原風景の所産の一部になっている はずである。

\section{（2）一番感動した自然風景を体験した年}

一番感動した自然風景を体験した年を図一 1 の $\square$ 印と図 -3 に示した。図ー1 からわかるように一番感動した自然風景は20 才以上で体験することが多い。図一 $3^{10)}$ より，1 年前に一番感動

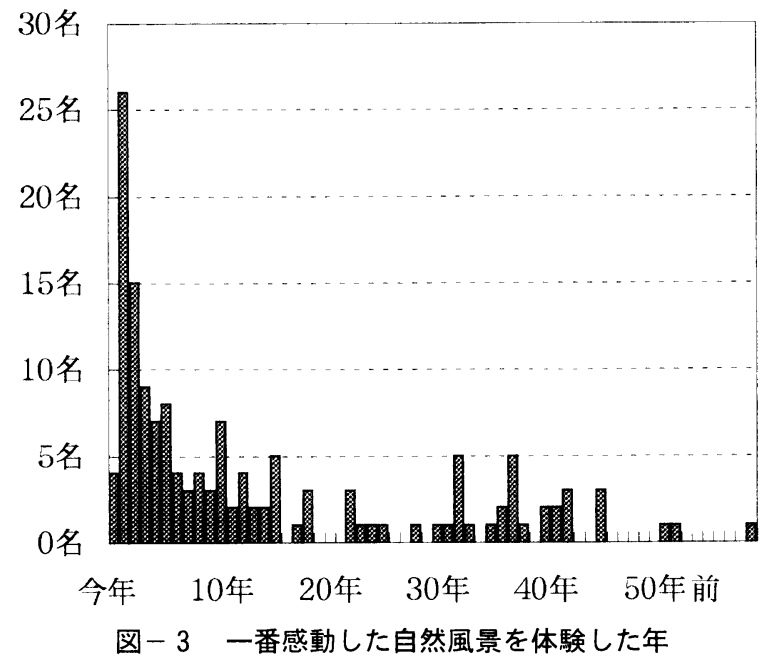




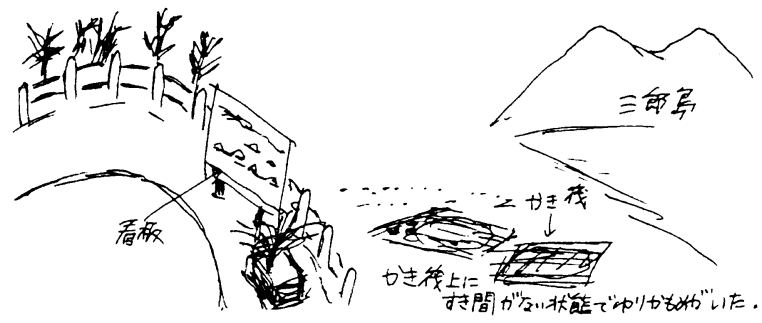

図－４一番感動した場所のイメージ絵の例

した自然風景を体験した人が 26 名で最も多く。全体の半数の人 が 6 年以内に一番感動した自然風景を体験している。時が経つと 記憶が薄れるのと同じように自然風景の強い感動も時が経つと薄 れる。このため，感動が薄れずに残っている近年に体験した自然 風景を一番感動した自然風景と回答してる。また，写真を趣味に した人達を調査対象にしたことにより風景を写真の成果品として 捉えてしまう危険性から，一番感動した自然風景の体験が近年に 多くなったとも考えられる。一方，10 年前より以前に体験した 自然風景を一番感動したと回答した人が $43.2 \%$ おり，長い時間 を経ても感動が維持される場合も多数あることがわかった。

\section{4. 自然風景の視点場と視対象}

\section{（1）視点場と視対象の解析方法}

景観とは眺めている人と見ている環境から成り立つものである。 本研究では, 自然風景を体験した場所を視点場, 眺めている対象 を視対象"”之呼ぶことにした。視対象には，見ている風景の構成 要素だけでなく, 紅葉や朝日などの風景の現象の記述も含めて解 析している。

初めて思い出に残った自然風景を答えてくれたのは 173 名であ る。一番感動した風景を答えてくれたのは，179名でそのうち地 図を描いてくれた人は 99 名, イメージ絵を描いてくれた人が 31 名だった。イメージ絵の例を図ー4に示した。このような図と記 述式の設問を基に解析を加えた。視点場之視対象の設問の回答は, 回答者自身の言葉で記述してもらった。自由記述の結果をそのま までは集計することが難しいので，似た回答を集めてグループを 形成した。グループ編成過程では小グループから大グループに編 成されて行くが, 説明がしやすいように階層化されたグループを 大きいものから第 1 グループ, 第 2 グループの順に呼称した。図一 5 では，第 1 グループは最む大きいグループであり，グループの 名称をそれぞれ [静止視点場] [移動可能視点場］とした。第 2 グループは，その下にくる階層で，「山」「水辺」「農村」などか らなり，第3グループは「山」「草原」などからなる。さらに最 下層に,「山頂」「山」「尾根」などが構成要素として整理された。
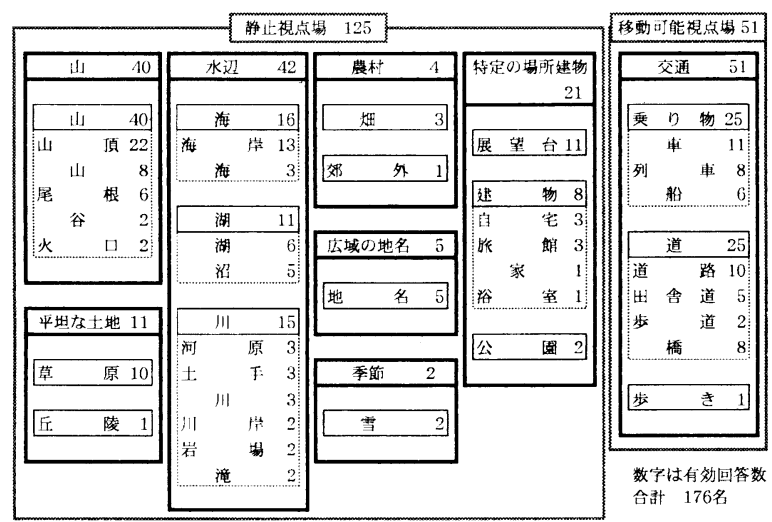

図－5 初めて思い出に残った自然風景の視点場

\section{（2）初めて思い出に残った自然風景}

初めて思い出に残った自然風景の視点場をまとめた図一 5 を見 てみると, 第 1 グループでは, [静止視点場] が 125 名, [移動可 能視点場］が 51 名である。[静止視点場］は［水辺(42名)］［山 (40名)］[特定の場所建物(21名)］などから構成されている。第 3 グループで 10 名以上の回答のあったグループは，[山(40 名)] [乗り物(25名)］[道(25名)］[海(16 名)］[川(15名)］［湖(11 名)］[展望台(11名)］[草原(10名)］である。第 3 グループで数 の多い [山］の視点場としては, 山頂, 山, 尾根などからなり, [乗り物］は, 車, 列車, 船などからなる。[道］の視点場として は, 道路, 橋などからなる。初めて自然風景を体験する視点場と しては, 山頂や海岸，草原などの自然環境が重要である。また， 展望台や橋, 車や列車の走る道路なども景観体験の視点場として 重要である。

図一6は，初めて思い出に残った自然風景の視対象をまとめた。 第 1 グループの視対象は [空間的視対象 (143名)] [時間的視対 象（43名)][経験・心象 (6名)］[移動可能視対象（5名)］で あり, 合計 197 名である。視対象に「山並みと夕焼け」,「火口と 噴煙」などのように複数の答えを記述した場合, 視対象として 2 度カウントしたため, 回答者数の 183 名より多くなった。 [空間 的視刘象］は, 山や水辺, 平坦な土地, 農村, 植物あるいは特定 の建物などのグループである。[移動可能視対象］は，鳥や馬な どの動物などの生き物や船などの乗り物のグループである。[経 験・心象]は, 人間の行為の経験や, 詩や歌に記述された景色の 心象風景などのグループである。[時間的視対象］のグループは, 夕甘や朝日, 雲などの [時間変化] のグループと, 新緑, 紅葉な どの [季節変化 $]$ のグループからなっている。第 2 グループを回 答数の多い順に並べる之, [山・山並み(74名)] [水・水辺(43名) ] [時間変化(31名)]などである。[山・山並み］の回答者数は, 全回答者 197 名の $36 \%$ を占めいている。第 3 グループでは, [山 (57名)] が最も多く, 次に [海(18名)] [太陽(18名)］となっ ている。

設問が自然風景を対象にしているので，[山・山並み］のグルー プが多くなるのは当然であるが, 工作物や船, 田などの人工物が 視対象亡なる場合や, シジミ採りや魚釣りなどの人間の行動が自 然風景体験の一部となっている場合もあった。また, 天候の変化 や太陽の変化など時間変化がもたらす体験や, 春, 秋, 冬などの 季節変化の体験などがあり, 思い出の自然風景が物理的空間的対 象之, 変化要因から構成されていることがわかった。さらに, 人

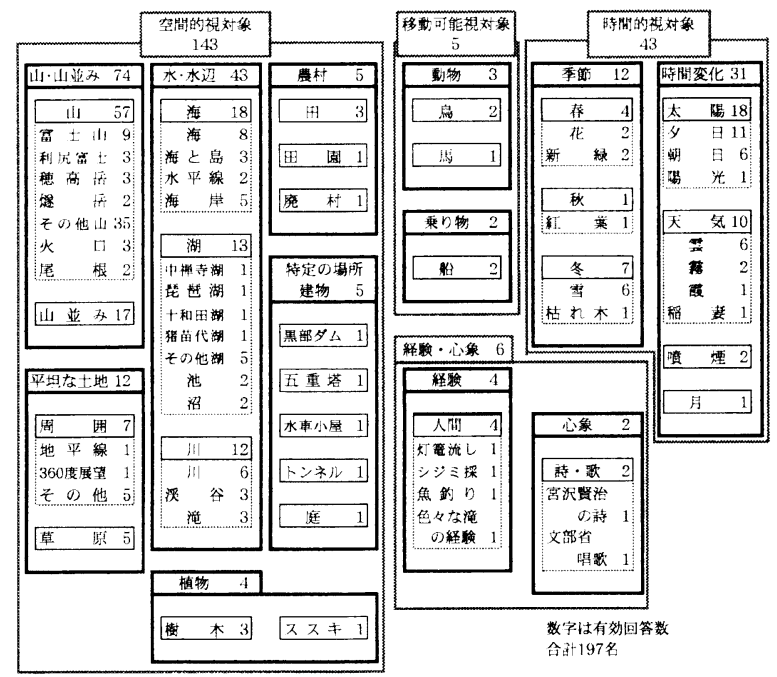

図ー6 初めて思い出に残った自然風景の視対象 
間の経験や心象が感動する自然風景体験の一部を成していると考 えられる ${ }^{3)}$ 。

\section{（3）一番感動した自然風景}

一番感動した自然風景は，初めて思い出に残った自然風景を体 験した後, 数多くの自然風景を体験した中で最も感動した風景で ある。

一番感動した自然風景の視点場を図一 7 にま之めた。第 1 グルー プは [静止視対象 (149名)] [移動可能視対象（34 名）］加らな る。第 2 グループを回答数の多い順に並べると, [山(65名)] [水辺(38 名)］[交通(34 名)］[特定の場所建物(24名)］[平坦な 土地(17名)］[農村(3 名)］[広域の地名(2名)］となる。 第 3 グループで多い順に並べると，[山（65名)］[湖（22 名)］ [道 (21名)］[展望台（15名）］海（12名）］である。

一番感動した自然風景の視対象を図一 8 にまとめた。第1 グルー プは，[空間的視対象（143 名)］[時間的視対象（50名）］[移動 可能視対象 (5 名)] からなり, 合計 198 名である。[空間的視対 象］のグループは, [山・山亚み (74 名)] [水・水辺 (44 名)] [平坦な土地（9名)］[植物（7名）］[農村（6名）］[動物（4 名)］[特定の場所建物（3名）］からなる。[時間的視対象］のグ ループは, 朝日, 夕日, 雲などからなる [時間变化 $(40$ 名 $)]$ と 雪，樹水，紅葉などからなる [季節（10名）］からなる。

初めて思い出に残った自然風景の視点場で回答数の割合を見て みると [静止視点場］と [移動可能視点場］の割合が $71: 29$ な のに対して,一番感動した自然風景の [静止視点場］と[移動可 能視点場]の回答数の割合が $81: 19$ となっている。一番感動し た自然風景の [静止視点場] の割合が増加し, [移動可能視点場] の割合が減少している。これは，一番感動した自然風景の視点場 における [山］の回答数が増加し, [乗り物］の回答数が減少し たためである。

また，初めて思い出に残った自然風景の視対象と一番感動した 自然風景の視対象を比較すると，初めて思い出に残った自然風景 の視対象にあった [経験・心象］がなくなっている。この他の [空間的視対象］[時間的視対象］［移動可能視対象］には大きな 違いは見られない。

初めて思い出に残った自然風景と一番感動した自然風景の視点 場と視対象を整理することにより, 思い出の自然風景の構成要素 を分類することができた。人間は初めて思い出に残った自然風景 の後に数多くの自然風景を体験する。その体験の中から最も感動 した自然風景を回答してもらったが両者に大差がないということ は，アンケートの設問で自然風景という限定を加えたことにより， 結果の構成要素が限定されたとも考えられるが, 自然風景の感動

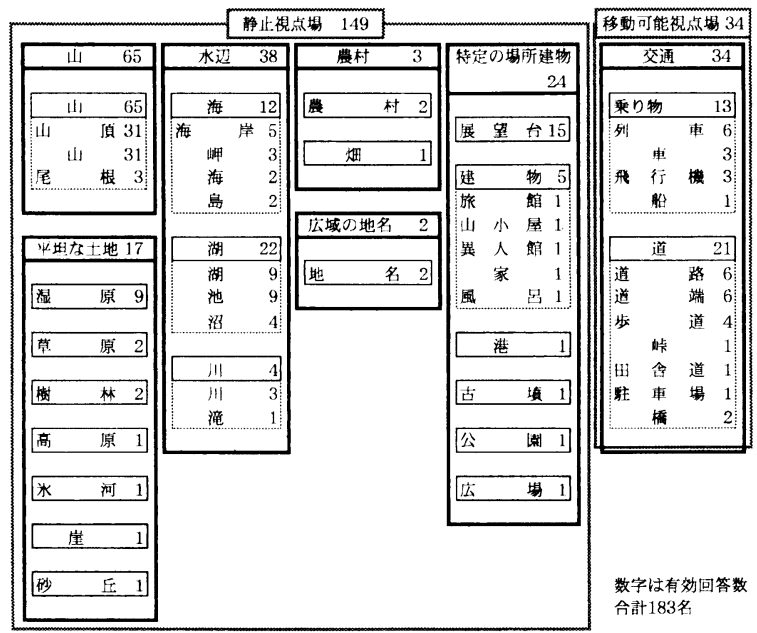

図ー7 一番感動した自然風景の視点場
の源泉は, 初めての時も経験を積み重ねた後もあまり変化しない と考えられる。

\section{5。一番感動した自然風景を体験した時の状況}

今までに一番感動した自然風景を体験した時の状況を調査した 結果を図ー9〜図ー16に示した。

図-9 の体験した月は, 10 月が 30 名, 8 月が 26 名, 7 月が 17 名であり, 夏と秋が多い。夏は, 夏休みがあり旅行シーズン でもあるため体験する機会が多いためと考えられる。秋は, 四季 の移り变わりの中で, 最も彩りが鮮やかで, 初秋から晚秋にかけ て自然風景全体の色合いの変化も大きいため, 感動することが多 い。

図-10 の体験した時間は, 6 時が 34 名, 7 時 15 名であり, 朝に体験することが多い。午前中と午後の比較をすると, 午前中 111 名, 午後 44 名である。午前が有効回答数の $72 \%$ 占めてい る。夜明け後しばらくの 6 時が極端に多いのは写真撮影を趣味に している人を対象にしている特徴をよくあらわしている。朝夕は 光の変化により刻々之風景が変化し, 朝狫けや夕焼けを体験する ことができる。また, 太陽光が低いため斜めの光を受けるので, 陰影がはっきりして立体感がでるために写真撮影に向いている。 この他に午前が多い理由としては, 午前中大気が澄んでいて遠方 まで見えるのに対して, 午後になると空気中に水蒸気があがって しまい視界が落ちることも理由として考えられる。さらに, 朝早 起きをして散歩をするとすがすがしさを感じるように, 朝の時間 帯がもつ風景以外の要因も大きいかもしれない。

番感動した自然風景の空の状態を, 天気と陽射しと風景の明 るさについて調査した。図-11の天気では, 快晴が 77 名, 晴れ が 41 名, 曇が 26 名であった。陽射しの設問では, 回答に陽射し の強さを述べた人と, 陽射しの特徴を述べた人がいたので, 別々 に分けて集計した。図一12 の陽射しの強さでは, 強が 35 名, 良 好が 17 名, 無しが 15 名であった。図-13 の陽射しの特徴では, 朝焼・夕焼が 25 名, 斜光が 10 名, 柔らかが 8 名, 部分が 7 名で あった。図-14の明るさは, 薄暗いが 48 名, 明るいが 35 名, 良好が 29 名であった。空の状態が, 快晴あるいは晴れていて, 陽射しが強く, 明るい場合に, 感動することが多い。また, 陽射 しが無しあるいは薄日の状態で, 明るさが薄暗い, 朝や夕方の風 景も感動することが多い。

一番感動した自然風景の温度, 風を調べた結果, 図ー15の温 度は 10 度が 13 名, 20 度が 12 名, 15 度が 9 名となった。しかし ながら，風景を体験したときに温度計で測った人はほとんどいな いので，今回の設問では, 感覚的に答えていると推察される。こ

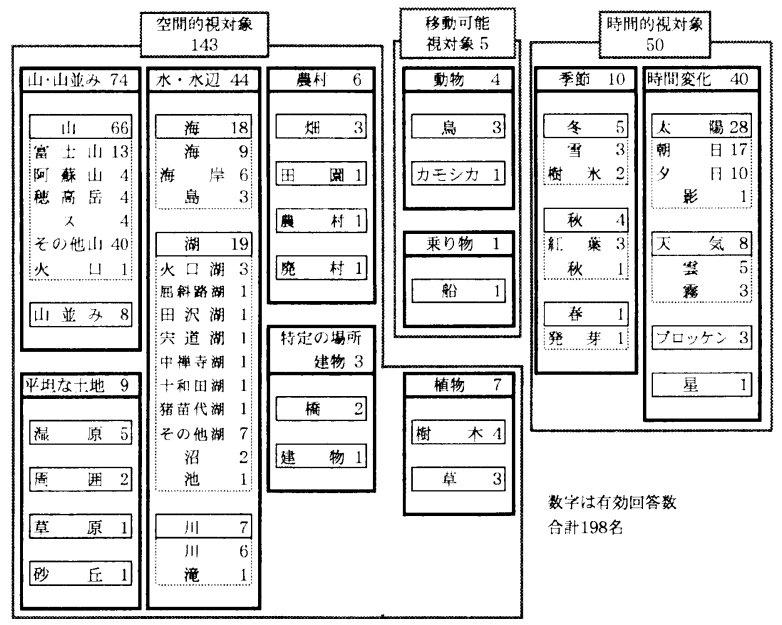

図ー8 一番感動した自然風景の視対象 
のため, 回答が, 切れの良い 10 度や 15 度, 20 度などに集まっ てしまった。そこで，全体的な傾向を見るために，移動平均を取 ることにした。移動平均の間隔は, 回答のピークが 5 度ずつくる
ことから, 前後 2 度ずつの 5 度の範囲の移動平均を求めた。この 結果，感動した自然風景を体験した温度は 0 度前後から 20 度前 後の間で体験することが多いことが明らかになった。26度以上

の高い温度が少ないの に比較して, -10 度 を回答した人が 6 名い る。これは，樹水や雪 の風景などの季節感の ある冬景色の場合であ る。困-16の風では, 無風 81 名, 微風 30 名 であった。自然風景の 体験では, 風による感 動体験への効果は少な いようである。

\section{6. おわりに}

本研究では, 思い出 に残った自然風景の体 験年齢, 視点場と視対 象，体験した状況を整 理することにより，思 い出に残る風景の特徵 の分析を試みた。今回 の研究報告の成果とし て以下の点があげられ る。

1) 初めて思い出に 残る自然風景は，ほ之 んごの場合 20 才以下 で体験し, 幼少期 (3 才〜 8 才比）よりも思 春期（10才〜20才頃） に体験する場合が多い。

2) 一番思い出に残 る自然風景は，全体の 半数の人が 6 年以内に 体験している。一方, 10 年前より以前に体 験した自然蚛景を一番 感動したと回答した人 も多数いることから， 長い時間を経ても感動 が維持される場合も数 多くあることがわかっ た。

3 ) 初めて思い出に 残った自然風景の構成 要素之一番感動した自 然風景の構成要素に大 差はなく, 自然風景の 感動の源泉は初めての 時も経験を積んだ後も あまり変化しないと考 えられる。

4) 思い出に残る自 然風景の構造は, 視点 場の特性によって視対 
象の見え方が変化している。視対象は, 物理的対象物の空間分布 を視知覚で認識しているのに加え，時間や季節の変化要因が自然 風景に彩りを加えている。

5 ）思い出の自然風景を体験した月は, 夏と秋が多く, 体験時 間は朝と夕が多くなっている。特に午前中に $72 \%$ が体験している。 空の状態は, 快晴あるいは晴れていて, 陽射しが強く, 明るい場 合に，感動することが多い。また，陽射しが無しあるいは薄日の 状態で, 明るさが薄暗い, 朝や夕方の風景も感動することが多い。 感動した自然風景を体験した温度は 0 度前後から 20 度前後の間 で体験することが多く，風による感動体験への効果は少ないよう である。

\section{参考引用文献及び補注}

1) 古谷勝則, 麻生恵, 青木陽二(1997)： 景観研究の流れと今後 : ランドスケー プ研究 61(1)，77

2 ）堀繁，栗原正夫，篠原修 (1988）: 体験 された風景の構造：造園雑誌 51(5), 287-292

3 ）茂原朋子, 渡部貴介, 十代田朗(1991): 青年の“原風景”の特性と構造に関 する研究: 都市計画学会学術研究論文 集, 457-462

4 ) 平尾和洋, 宮嶋聡, 川崎清 (1995): 「好きな景観」写真展にみる景観読解 過程と景観タイプ：日本建築学会計画 系論文集 第472 号, 123-132

5 ）周静敏, 服部岑生, 真境名達哉(1995)： 居住体験と住環境の理想像の類型：日 本建築学会計画系論文集 第 477 号, 63-70
本論文では, 思い出に残る自然風景の体験年齢, 視点場と視対 象, 体験した状況を明らかにした。今後, 分類した視対象のグルー プ別に特徴的な景観の類型化を行い，類型別の体験状況の特徴の 違いを明らかにする予定である。

この研究は, 環境庁国立環境研究所の青木陽二主任研究官と共 同で行ったアンケートの成果を用いて執筆した。著者を環境庁国 立研究所の共同研究員として採用する労をとり，結果のとりまと めに適切なアドバイスを頂いた青木陽二主任研究官に感謝の意を 表する。また，調查の実施にあたって名簿の便宜をはかって下さっ た（財）国立公園協会の塚本辰雄氏と油井正昭千葉大学教授にも 感謝する。
6 ) 東京農業大学庭園学・造園学原論研究 室(1996)：原風景の研究：東京農業大 学出版会, $286 \mathrm{pp}$

7 ）青木陽二, 古谷勝則(1997)：『自然風 景の思いでに関する調查』の結果につ いて：国立公園 557, 18-21

8 ) 茂原ら ${ }^{3)}$ の図から小数点以下の年齢 の頻度まで読み取れなかったので，近 似の整数値に置き換えてグラフ化した。

9 ) 東京農業大学農学部造園学科造園用語 辞典編集委員会(1985)：造園用語辞典： 彰国社, 173

10）図一 3 で, 今年体験した人の人数が 4 名と少ないのは，4月に調查したので 冬から春先の期間の体験しか回答され ていないためである。

11）篠原 ${ }^{12)}$ の操作的景観把握モデルでは, 景観構成要素を視点, 視点場, 主対象, 対象場でとらえている。本研究のアン
ケート結果からは, 操作論的景観把握

モデルでいうところの主対象が対象場 のよ゙こにあるのか，あるいは自然風景 が主対象であるか対象場であるかを， 判断できない。また, 紅葉や朝日なよ゙ の風景の現象の記述を対象場に含める ことができない。そこで，眺めている 対象を視対象と呼ぶことにした。

12）篠原修(1977)：土木工学大系 13 景観 論 : 彰国社, 50-51

13）樋口忠彦(1975）：景観の構造 : 技報堂, $168 \mathrm{pp}$

14）ケヴィン・リンチ著，丹下健三，富田 玲子䚿(1968)：都市のイメージ：岩波 書店, $276 \mathrm{pp}$

15）小林享(1993）: 移ろいの風景論：鹿島 出版会, 277pp

16）高橋進(1982）：風景美の創造之保護： 大明堂, 206pp

Summary : From the moment they were born they gradually become aware of their surrounding. And, they experience many landscapes, and gain the memory of landscape. This paper aims to reveal what scenes they regard as the memory of landscape, and when they gain the memory of landscape. The results are as follows;

1) Points of view in natural landscape are not only top of a mountain, coast, and meadow but also road and observatory and dridge.

2 ) The structure of natural landscape are recognized the spatial distribution of objects. In addition, the changeable factors of time and season influence the recognition of natural landscape.

3 ) The $72 \%$ of them gain the memory of landscape in the morning.

4) They often gain the memory of landscape when it is fine weather and bright sunshine.

5 ) There are few influence of temperature and wind. 